\title{
Performance evaluation of a passive house in sub-arctic climate
}

\author{
Shimantika Bhattacharjee*[0000-0001-9279-2233], Sofia Lidelöw ${ }^{[0000-0003-0974-2142]}$ and Jutta \\ Schade ${ }^{[0000-0003-2402-1845]}$ \\ Department of Civil, Environmental and Natural Resources Engineering, Luleå University of \\ Technology, 97187 Luleå, Sweden \\ shimantika.bhattacharjee@ltu.se
}

\begin{abstract}
As the operational energy use in buildings contributes highly to the total energy used and greenhouse gases emitted in the cold climate regions of Europe, buildings which are more energy-efficient and less carbon-intensive during operation are key to meet sustainability objectives in these regions. Yet, research shows that the practice of passive or low-energy buildings in the sub-arctic climate of northern Sweden is comparatively less than in the southern region. Moreover, previous studies did not explicitly examine the performance of low energy buildings in sub-arctic climate in relation to established building energy efficiency standards. Consequently, knowledge regarding the energy performance of low-energy buildings in such climate is limited. Therefore, the aim is to evaluate the performance, in terms of indoor temperature and energy use for heating, domestic hot water and electricity of a new-built passive house titled "Sjunde Huset" in the sub-arctic town of Kiruna. It is Sweden's northernmost house designed to fulfil the Swedish passive-house criteria of a maximum heat loss factor of $17 \mathrm{~W} / \mathrm{m}^{2}$ and a maximum annual energy use of 63 $\mathrm{kWh} / \mathrm{m}^{2}$. The implemented passive design strategies include a highly insulated, compact and airtight building envelope with a vestibule, mechanical ventilation with heat recovery and renewable energy production through photovoltaic solar cells. The house is connected to district heating and is equipped with energyefficient appliances to allow low occupant energy use. Ongoing performance evaluation is based on building simulation and measurements of energy and temperature in different zones of the building. Energy performance deviations between occupied and non-occupied zones are explored through internal heat gain evaluations. The indoor temperature is also evaluated to assess the temperature variations throughout the year. The ongoing research further evaluate a comparative simulated and measured energy analysis of heating, hot water and electricity based on both the international passive house standard and the Swedish passive house criteria "Feby 12".
\end{abstract}

Keywords: Passive house, sub-arctic climate, performance evaluation, energy efficiency, indoor temperature. 


\section{Introduction}

\subsection{Background and problem identification}

Technological advancements, infrastructure growth and urbanization have globally accelerated the energy used by human society. Building energy use is responsible for a significant amount of the total energy used worldwide. In Europe, different initiatives were taken into consideration for attaining the progressive sustainability objectives in the building sector. For example, the European Union (EU) set up a target for the year 2020 to improve the energy efficiency by $20 \%$ (from 1990 levels), reduce the GHG emissions by $20 \%$ and increase the share for renewable energy sources by $20 \%$.

The operational energy use in buildings contributes highly to the total energy used and the greenhouse gases emitted in cold-climate regions. Buildings that are more energy-efficient and less carbon-intensive during operation are therefore key to meet sustainability objectives in these regions. In southern Sweden, the number of buildings that are in compliance with the Swedish passive house criteria "Feby" is steadily increasing. However, realizing such energy-efficient houses in the sub-arctic climate zone of northern Sweden is more challenging due to the cold, long and snowy winters and the mild, short summers. Moreover, there exists a lack of systematic and documented measurements regarding the monitoring and analysis of the energyefficiency solutions, particularly solutions that have been developed and tested for this climate zone. Previous studies did not explicitly examine the performance of low-energy buildings in sub-arctic climate in relation to established building energy-efficiency standards. However, a few studies were found relevant for this particular study. Risberg et al (2015) performed an analysis of different heating systems in a single-family house situated in Kiruna and found that floor heating is the most efficient system in terms of achieving the desired indoor temperature and a comfortable indoor climate [1]. Another study by Mukhopadhyaya et al. (2014) regarding the application and thermal performance of vacuum insulation panel (VIP) in buildings situated in the northern Canadian city of Yukon, which is also in the sub-arctic climate zone showed that VIP, if appropriately designed and constructed, can be an attractive option for retrofitted building envelopes in such climate [2]. Vladykova et al. (2011) highlighted the challenges and potential technical barriers of building energy-efficient buildings in Greenland, which is under the arctic climate region. Yet, even though the arctic climate is more severe in terms of temperature, snow, wind and storms than the sub-arctic climate, Vladykova's et al. study gives some valuable insights. For example, it was found that a ventilation system with heat recovery needs to adjust to larger temperature differences and frequent condensation problems from air and snow can occur which may eventually reduce the heat exchanger efficiency [3].

Sweden's northernmost passive house, titled "Sjunde Huset", was built in the town of Kiruna in 2014 with the aim to develop, demonstrate and evaluate a passive house concept for the sub-arctic climate region. Kiruna has a sub-arctic climate, with monthly temperatures normally averaging below $0{ }^{\circ} \mathrm{C}$ during October to April and just above 10 ${ }^{\circ} \mathrm{C}$ during July to August. Being situated well above the Arctic Circle, it also 
experiences a pronounced seasonal cycle of solar radiation with only around $15 \%$ of the annual hours of sunshine hours occurring during the five coldest months between October and February. Consequently, the house receives small heat gains from solar radiation during the period when the need for heating is greatest. The energy used for space heating the existing buildings in the sub-arctic part of northern Sweden is comparatively higher than the Swedish average, which raises prospect for reducing the region's overall energy use through constructing more energy-efficient houses such as passive houses. In"Sjunde Huset" passive strategies were selected and evaluated based on their performance effectiveness in cold climate. According to a recently published report by NCC (2017), which presents the construction process, the technical installations and the first measurement results from "Sjunde huset", the energy use for heating and hot water was estimated using building energy simulations to $54 \mathrm{kWh} / \mathrm{m}^{2}$, year, which would fulfil the Swedish passive-house requirement of $63 \mathrm{kWh} / \mathrm{m}^{2}$, year.[4]

As part of an on-going performance evaluation of "Sjunde Huset", this paper presents and contrasts design-stage simulations and measured data for one year in terms of energy use and indoor temperature of the building. Since there is no established standards for energy-efficient buildings in sub-arctic climate this study can serve as an inspiration for future passive or low-energy house practices in northern Sweden. Building energy efficient houses in sub-arctic climate is challenging due to the extreme climate conditions. Yet, a few demonstration projects have been performed in northern most Sweden but characteristic of most of these is the lack of systematic and documented measurements and evaluations of the implemented energy-efficiency solutions during operation. The on-going performance evaluation of "Sjunde Huset" seeks to contribute to fill this gap.

\subsection{Aims and objectives}

The aim is to make a simulated and measured comparative analysis in terms of indoor temperature and operational energy use between an occupied and non-occupied zone of the passive house "Sjunde Huset". More specifically the objectives are to:

- Evaluate certain discrepancies between the simulated (design-stage) and measured (operational-stage) energy performance.

- Evaluate the indoor temperature to assess the variations throughout the year.

- Evaluate the simulated and measured performance based on both the international passive house standard and the Swedish passive house criteria. 


\section{Method}

The passive house titled "Sjunde huset" has a heated floor area of $280 \mathrm{~m}^{2}$, which is equally distributed between two apartments. One of these apartments (hereafter referred to as "apartment 2") was selected as a case for this particular study, which is divided into three phases.

First, dynamic simulations were performed in IDA ICE advanced version 4.7(Equa, Sweden) to replicate the building's energy use as it was estimated by the contractor in the design stage. Furthermore, measured energy use for one year of operation was collected. Discrepancies between the design stage and operational stage energy use in occupied and non-occupied zones were analyzed.

Second, measured indoor temperatures in different rooms of apartment 2 were collected for the studied year. Annual measured data for space heating that enabled a comparison between the measured and simulated heating energy use was available only for apartment 2, which was a motivation for selecting apartment 2 as the study object here. The third phase includes the comparison between the simulated and measured energy use of "Sjunde huset" with both the Swedish passive house criteria (Feby) and the international passive house standards.

\subsection{Description of the passive house "Sjunde Huset"}

"Sjunde Huset" is a two-storey house which contains two separated apartments with a heated floor area of $140 \mathrm{~m}^{2}$ each (see Figure 1 and 2). The house is developed from NCC's conceptualized house to an energy-efficient passive house to fulfill the Swedish passive house criteria "Feby". As such, it has a highly insulated, airtight and compact building envelope (see Table 1) with vestibules that reduce air infiltration through the entrance doors. The house is also equipped with mechanical exhaust and supply air ventilation system with heat recovery to minimize the ventilation heat losses and energy-efficient lighting and appliances. Space and hot-water heating is provided through district heating which is converted to air heating via a heating coil. The "Nasa Shower" being equipped with water recycling potential is estimated to reduce the energy for each shower by $80 \%$ and water use by $90 \%$. Each apartment is equipped with around $15 \mathrm{~m}^{2}$ of solar panels for electricity production. The solar panels are placed vertically on the façade to make use of the reflection from snow and to minimize snow accumulation. The roof is green with sedum plants, herbs and grasses. The appliances such as washing machine and dishwasher is connected to the district heating. Energy efficiency measures along with innovative techniques has been implemented in this case study building to reduce the heating, domestic hot water use and electricity use. 


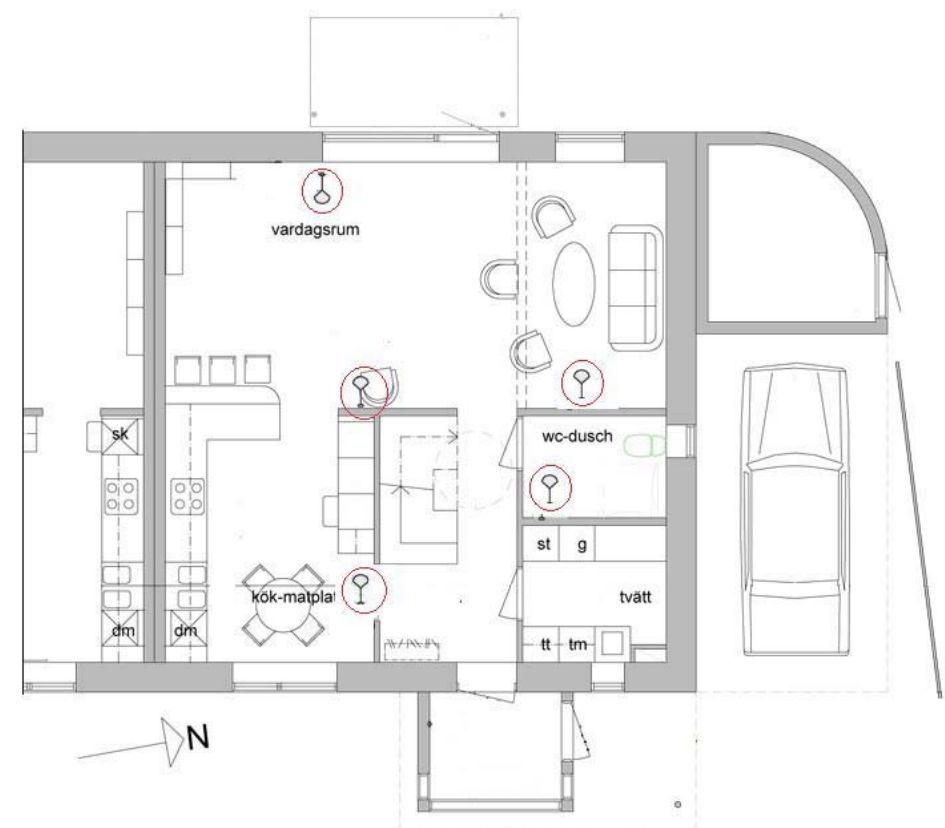

Fig. 1. Ground floor plan of the passive house "Sjunde Huset". The red circles represent the sensors placed inside the house for measuring indoor temperature.

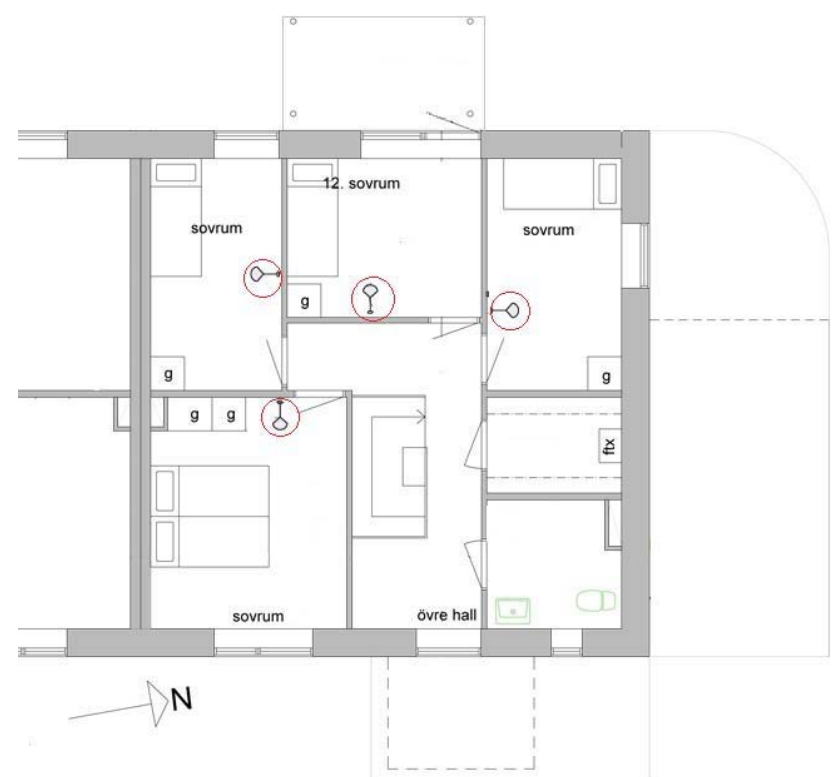

Fig. 2. First floor plan. The red circles represent the sensors placed inside the house for measuring indoor temperature. 


\subsection{Input data}

Table 1. Thermal characteristics of the building envelope. Source: NCC, 2017

\begin{tabular}{l|l|c}
\hline Building parts & \multicolumn{1}{|c}{ Construction } & U-value $/\left(\mathrm{W}\left(\mathrm{m}^{2} /(\cdot \mathrm{K})\right)\right.$ \\
\hline External wall & $\begin{array}{l}50 \mathrm{~mm} \text { façade panel,6mm Minerit board, 120mm } \\
\text { Mineral Wool/studs cc600,140mm PIR,45mm } \\
\text { Mineral Wool/studs cc 450,13mm Plasterboard }\end{array}$ & 0.079 \\
\hline Roof & $\begin{array}{l}\text { 1000 mm loose-fill Mineral Wool insulation } \\
\text { including studs }\end{array}$ & 0.0349 \\
\hline Intermediate floor & $\begin{array}{l}\text { Double gypsum on 95mm frame, 30mm light } \\
\text { insulation }\end{array}$ & 0.6187 \\
\hline External floor & 100mm concrete and 400 mm cellular plastic & 0.0756 \\
\hline Window & $\begin{array}{l}\text { Triple pane glazing, g-value was considered as } \\
0.37\end{array}$ & 0.65 \\
\hline Door & Wood & 0.7 \\
\hline $\begin{array}{l}\text { Overall heat loss } \\
\text { coefficient }\end{array}$ & - & 0.16 \\
\hline
\end{tabular}

Table 2. Input data for "Sjunde Huset" used for design stage simulations. Source: NCC, 2017

\begin{tabular}{c|c}
\hline Infiltration rate $\left./\left(\mathrm{L} / \mathrm{s} \cdot \mathrm{m}^{2}\right)\right)$ at $\pm 50 \mathrm{~Pa}$ pressure difference & 0.05 \\
\hline Building envelope area $/ \mathrm{m}^{2}$ & 527 \\
\hline Heating $/{ }^{\circ} \mathrm{C}$ & 21 \\
\hline Cooling $/{ }^{\circ} \mathrm{C}$ & 25 \\
\hline HVAC template & $\mathrm{CAV}$ \\
\hline
\end{tabular}

\subsection{Measurement data}

Energy and temperature data for the entire year of 2016 was analyzed. Energy data for heating energy use in apartment 2 was collected from the district-heating meter and supplied by Tekniska Verken i Kiruna AB. Apartment 2 was essentially non-occupied throughout the analyzed year; hence, the measured values represent the space heating use as no domestic hot water was used during that period. This facilitated the comparison between the simulated non-occupied heating energy use and measured nonoccupied heating energy use. 


\section{$3 \quad$ Result and analysis}

\subsection{Simulated and measured energy use}

According to the aggregated results shown in Table 3, the simulated heating energy use is higher than the measured heating energy use for the analyzed year. The simulated and measured energy use varies since the measured energy use was obtained through static metered data, while, on the contrary, the simulated energy use was obtained through dynamic simulations. According to the simulations, the heating energy use is higher for the non-occupied situation than for the occupied situation. This is mainly due to the lack of internal heat gains from occupants and their use of electric equipment and hot water. Hence, more heat must be supplied by the heating system to maintain the setpoint indoor temperature, especially during the coldest months when the solar gains are minimal.

Energy use for DHW (domestic hot water) can be estimated to $20 \mathrm{kWh} / \mathrm{m}^{2}$ annually according to SVEBY [5]. However, "Sjunde huset" is equipped with "NASA" technology showers that recycle used water and provide an estimated energy saving of $80 \%$ [4]. That is why DHW use was estimated to $10 \mathrm{kWh} / \mathrm{m}^{2}$ in the design stage (see Table 3). When the apartment is finally occupied, measurement data will be gathered to analyze the actual energy savings of using this technology.

Table 3. Simulated and measured energy use in apartment 2 of the passive house "Sjunde Huset"

\begin{tabular}{l|c|c|c}
\hline \multirow{2}{*}{} & \multicolumn{3}{|l}{ Energy use $/\left(\mathrm{kWh} / \mathrm{m}^{2} \cdot\right.$ year $)$} \\
\cline { 2 - 4 } & $\begin{array}{l}\text { Simulated } \\
\text { occupied }\end{array}$ & $\begin{array}{l}\text { Simulated } \\
\text { non-occupied }\end{array}$ & $\begin{array}{l}\text { Measured } \\
\text { non-occupied }\end{array}$ \\
\hline Heating & 40 & 45 & 32 \\
\hline Domestic Hot water & 10 & 0 & - \\
\hline Kitchen ventilation losses & 1.7 & 0 & - \\
\hline $\begin{array}{l}\text { Ventilation losses through windows, } \\
\text { doors and other openings }\end{array}$ & 4 & 0 & - \\
\hline Auxiliary energy for fans and pumps & 4.9 & 4.9 & - \\
\hline Hot water circulation system losses & 0.6 & 0.6 & 32 \\
\hline Total energy use & 61 & 51 & \\
\hline
\end{tabular}


The monthly variations in the simulated energy use for heating, hot water and building electricity for the non-occupied scenario are shown in Figure 3. This scenario corresponds best to the real case since apartment 2 was essentially unoccupied throughout the measurement period presented in this paper. According to the simulation results shown in Figure 3, the heating energy use is decreasing towards the warmer summer months and starts to increase gradually towards the colder winter months. The simulated heating energy use show a maximum value of $1373 \mathrm{kWh}$ in January and a minimum value of $2.3 \mathrm{kWh}$ in June.

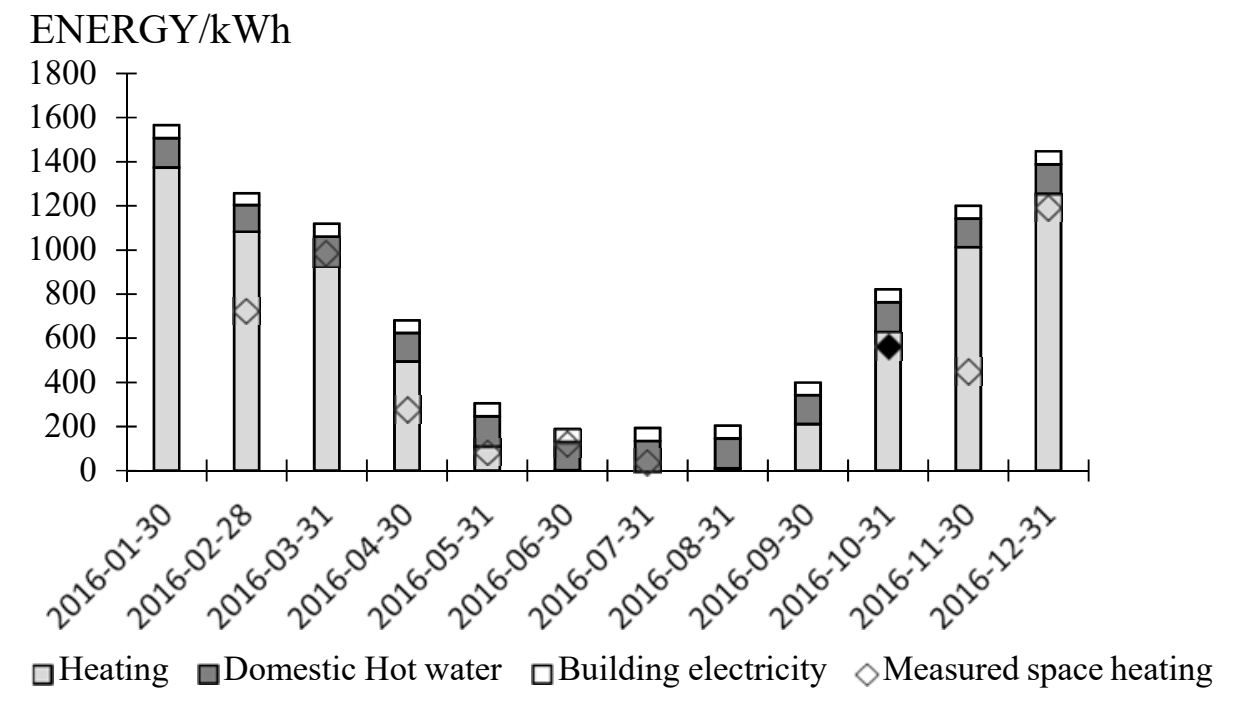

This value represents the accumulated energy measured from August till October

Fig. 3. Simulated unoccupied and measured unoccupied energy use for heating, domestic hot water and building electricity in "Sjunde Huset". Source of measured energy use: Tekniska Verken i Kiruna AB, 2016

As can be seen from Figure 3, the measured heating energy use has a similar trend over the year as the simulated heating energy use. Due to problems with the metering, the measured value shown for October represents the accumulated heating energy use during August to October. This could explain the slightly higher measured value for October than for November. 


\subsection{Indoor temperatures}

Temperature sensors were placed in different locations of apartment 2 in order to evaluate the indoor temperature throughout the year, see Figures 1 and 2 . Table 4 shows the evaluated temperature sensors and their respective placement.

Table 4. List of sensors and their respective placement in apartment 2

\begin{tabular}{l|c|c}
\hline Sensors & Place & Height from the floor level/meter \\
\hline GT10 & Living room (middle) & 1.59 \\
\hline GT11 & Living room (northeastern facade) & 1.60 \\
\hline GT12 & Near the staircase & 1.57 \\
\hline GT14 & Washroom(ground floor) & 1.58 \\
\hline GT15 & Bedroom 1 & 1.59 \\
\hline GT17 & Bedroom 2 & 1.57 \\
\hline GT18 & Bedroom 3 & 1.58 \\
\hline GT19 & Bedroom 4 & 1.57 \\
\hline
\end{tabular}

Table 5 shows the yearly average, minimum and maximum indoor temperature measured through each of the sensors during 2016. The sensors exhibited, to a varying extent, some erratic temperature data during the period of January until June. The erratic values were omitted before the calculations.

Table 5. Yearly indoor temperature obtained from measured data for different sensors during 2016

\begin{tabular}{c|c|c|c|c}
\hline \multicolumn{5}{c}{ Yearly indoor temperature $/{ }^{\circ} \mathrm{C}$} \\
\hline Sensors & Average & Maximum & Minimum & Available data \\
\hline GT10 & 19.3 & 27.2 & 15.1 & June-Dec \\
\hline GT11 & 19.2 & 26.6 & 15.0 & Feb-Dec \\
\hline GT12 & 20.0 & 27.3 & 15.0 & June-Dec \\
\hline GT14 & 19.0 & 25.9 & 15.0 & Feb-Dec \\
\hline GT15 & 20.0 & 29.2 & 15.0 & Feb-Dec \\
\hline GT17 & 19.6 & 34.1 & 15.0 & May-Dec \\
\hline GT18 & 20.0 & 28.0 & 15.1 & June-Dec \\
\hline GT19 & 21.1 & 33.4 & 15.1 & June-Dec \\
\hline
\end{tabular}

The average indoor temperatures ranged between $19^{\circ} \mathrm{C}$ and $21^{\circ} \mathrm{C}$ over the measured periods; this range is relatively low as $21^{\circ} \mathrm{C}$, is generally considered as optimum temperature indoor. The minimum indoor temperatures obtained from the sensors are only $15-16{ }^{\circ} \mathrm{C}$, which is due to the fact that the heating system did not work properly especially during October to November and, being an unoccupied zone, it took until November before anybody realized the problem. The maximum indoor temperatures of 33-34 ${ }^{\circ} \mathrm{C}$ were recorded in May and July for the sensors GT17 and GT19, respectively. This is a consequence of the fact that the zone was unoccupied. 
Occupants opening windows or doors could have contributed to reduce the indoor temperature as the maximum outdoor temperature recorded was as $24{ }^{\circ} \mathrm{C}$ in May and $25^{\circ} \mathrm{C}$ in July [6]. In this context, it should be noted that this passive house is not equipped with any active cooling system since it is situated in the sub-arctic climate with its short and cold to mild summers.

The above-mentioned section briefly described the indoor temperature variations throughout the year. Two specific months from summer and winter were chosen for deeper analysis of the temperature fluctuations (see Figure 4 and 5). More specifically, the aim of this part was to analyze whether the outdoor temperature could have influenced the indoor temperatures measured in "Sjunde huset". Outdoor temperature data for the year 2016 was collected from the nearest weather station which is situated 2.5 kilometers away from Sjunde Huset. [6].

\section{Temperature $/{ }^{\circ} \mathrm{C}$}

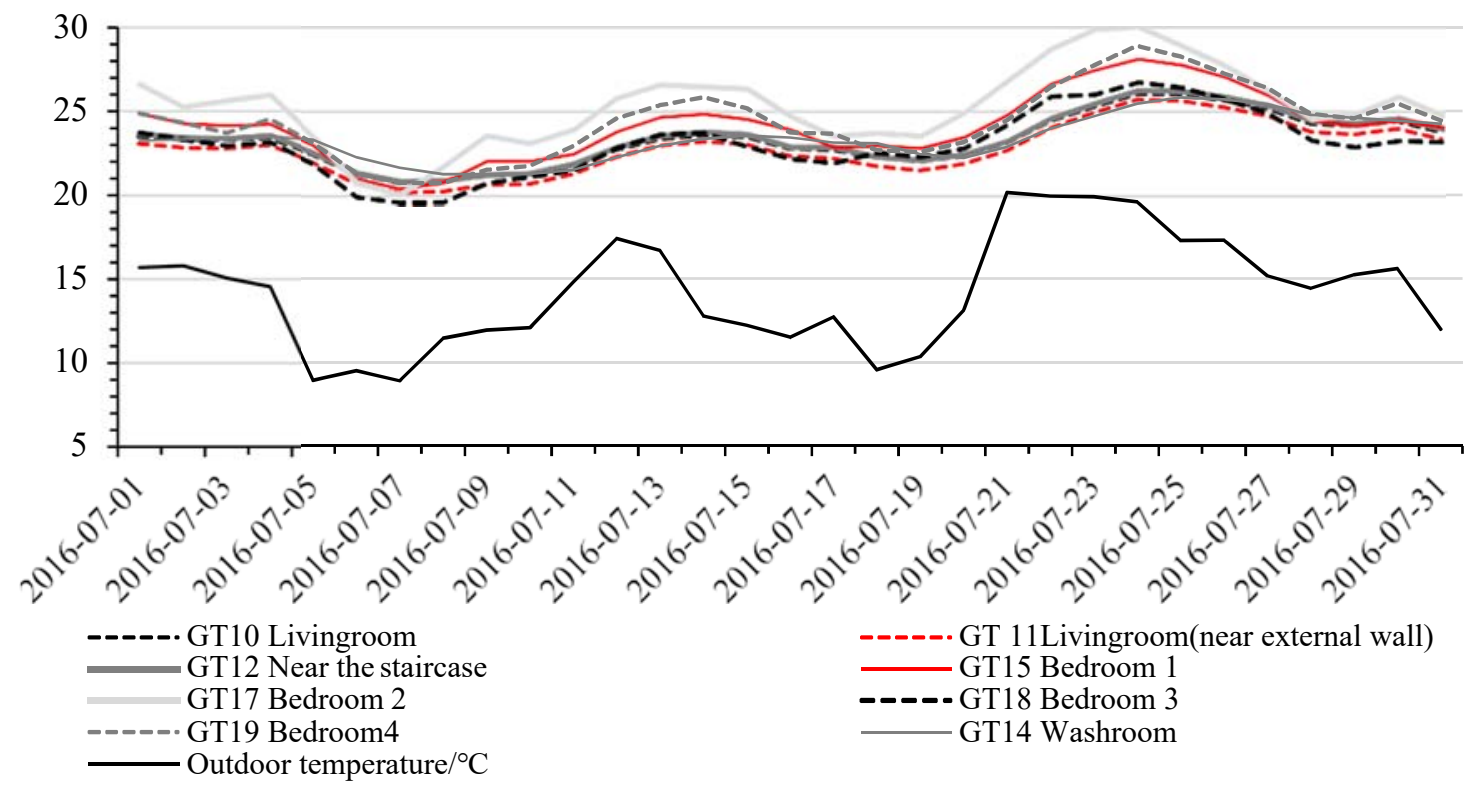

Fig. 4. Measured daily average indoor and outdoor temperature during July 2016.

Figure 4 shows the temperature variations indoor and outdoor during a typical summer month July. The $\mathrm{X}$-axis show the dates and the $\mathrm{Y}$-axis show the temperature range. The graph is showing similar trends for the indoor and outdoor temperature. The living room, which is situated on the ground floor level, has indoor temperatures ranging from $20{ }^{\circ} \mathrm{C}$ to $26^{\circ} \mathrm{C}$. The bedrooms, which are situated at the $2.8 \mathrm{~m}$ level have slightly higher indoor temperature than the zones situated on the ground level. The daily average temperature peaked at $30{ }^{\circ} \mathrm{C}$ in bedroom 2 during the third week of July although the recorded daily average outdoor temperature for that particular day was $20^{\circ} \mathrm{C}$. 
It seems that opening windows or ventilating the space could have helped to reduce the indoor temperature as the outdoor temperatures were mild and did not exceed $20{ }^{\circ} \mathrm{C}$ during July.

Figure 5 shows the indoor and outdoor temperature variations for the month of December. It can be seen from the graph that, being situated in the subarctic climate zone, the outdoor temperature is considerably lower than the indoor temperature as it is ranging from $0.9^{\circ} \mathrm{C}$ and $-19^{\circ} \mathrm{C}$.

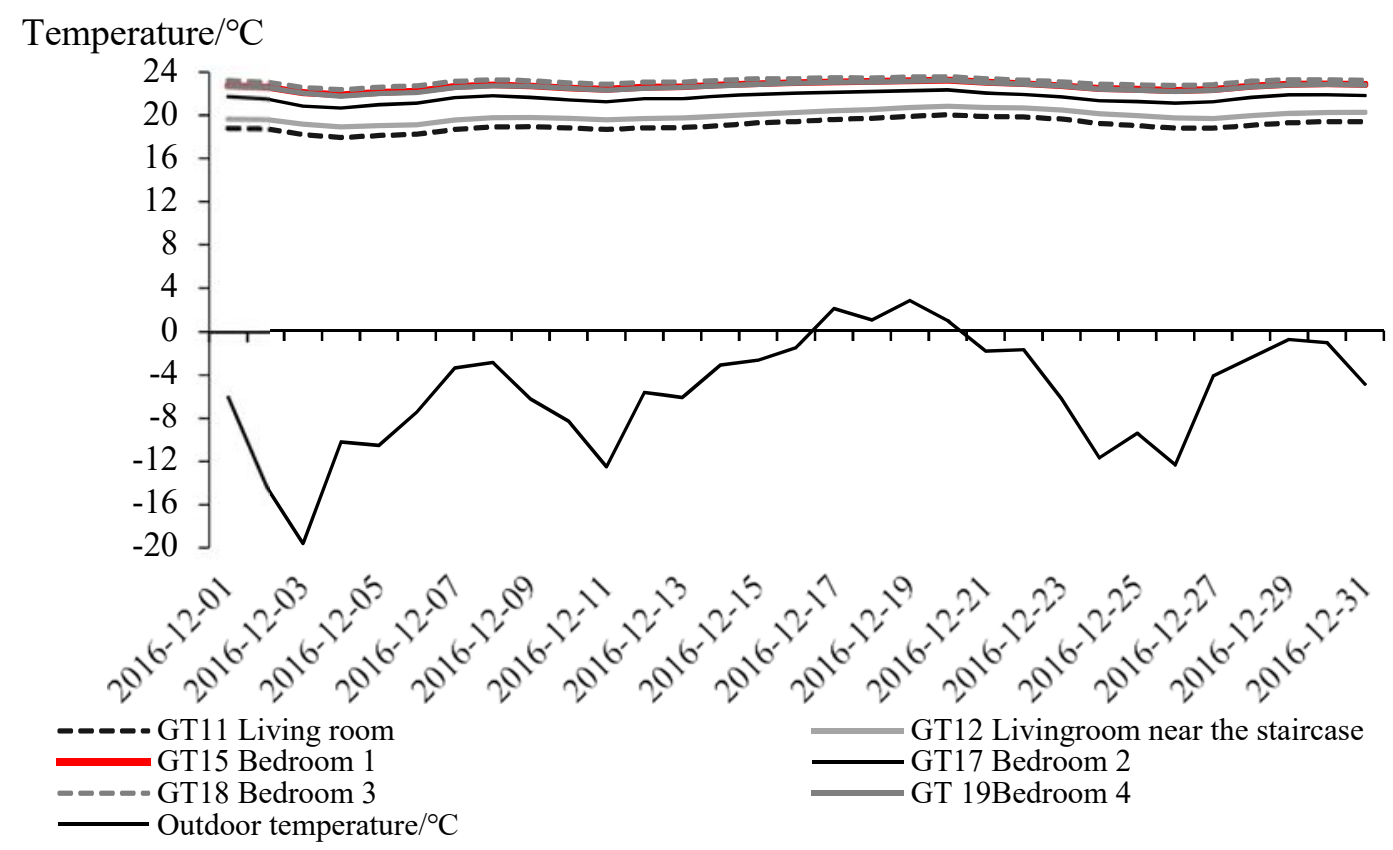

Fig. 5. Measured daily average temperature during December 2016

There were some issues regarding the battery of the heat exchanger, which was not working properly. The heating system was adjusted during November and therefore the indoor temperature in December show an optimum range between approximately $18^{\circ} \mathrm{C}$ and $23{ }^{\circ} \mathrm{C}$. However, zones situated on the first floor level had slightly higher temperature indoor compared to the temperature in the corresponding zones situated on the ground floor. 


\subsection{Comparison between the international passive house standard and Swedish passive house criteria (Feby)}

Table 6 shows different criteria of the international passive house standard [8] and the Swedish passive house criteria (Feby) [7]. According to the international passive house criteria the energy use for space heating should not exceed $15 \mathrm{kWh} / \mathrm{m}^{2}$. It is comparatively rigid compared to the Swedish standards for subarctic climate. The scenario is also true for peak heat load standards. The subarctic climate is more severe in terms of extremely lower outdoor temperature together with heavy snow and polar nights. During winter there prevails almost negligible amount of solar irradiation so it cannot contribute to internal gains when the need for heating is greatest. Therefore, it requires more energy for space heating to maintain an optimum temperature indoor. Therefore, it can be seen that the peak heat load is comparatively higher in the subarctic climate zone.

Table 6. Comparison between selected criteria of the international passive house standard and Swedish Passive house criteria (Feby)

\begin{tabular}{|c|c|c|}
\hline Input data & $\begin{array}{l}\text { International passive house } \\
\text { standard }\end{array}$ & $\begin{array}{l}\text { Swedish passive house criteria } \\
\text { (Feby) for sub-arctic climate }\end{array}$ \\
\hline Air leakage rate & $\mathrm{n}_{50} \leq 0,61 / \mathrm{h}$ & $\begin{array}{l}\text { Air leakage through the building } \\
\text { envelope at } \pm 50 \text { pa pressure } \\
\text { difference } \mathrm{q}_{50} 0.3 \mathrm{l} /\left(\mathrm{s} . \mathrm{m}^{2}\right)\end{array}$ \\
\hline $\begin{array}{l}\text { Heating energy } \\
\text { use }\end{array}$ & $\begin{array}{l}\leq 15 \mathrm{kWh} /\left(\mathrm{m}^{2} . \mathrm{a}\right)(\text { exclud- } \\
\text { ing Domestic hot water) }\end{array}$ & $\begin{array}{l}58 \mathrm{kWh} / \mathrm{m}^{2} \text { for non-electrically } \\
\text { heated home* and } 29 \mathrm{kWh} / \mathrm{m}^{2} \text { for } \\
\text { electrically heated houses** } \\
\text { (including domestic hot water) }\end{array}$ \\
\hline Peak heat load & $\leq 10 \mathrm{~W} /\left(\mathrm{m}^{2} . \mathrm{a}\right)$ & $17 \mathrm{~W} / \mathrm{m}^{2}, * *$ \\
\hline
\end{tabular}

$*+5 \mathrm{kWh} / \mathrm{m}^{2}$ for buildings with a heated floor area below $400 \mathrm{~m}^{2}$

$* *+2 \mathrm{kWh} / \mathrm{m}^{2}$ for buildings with a heated floor area below $400 \mathrm{~m}^{2}$

Both the simulated and the measured heating energy use (Table 3) shows that "Sjunde huset" fulfils the Swedish passive house criteria of $63 \mathrm{kWh} / \mathrm{m}^{2}$,year for a nonelectrically heated residential house with a heated floor area smaller than $400 \mathrm{~m}^{2}$ (Table 6) [7]. However, the comparatively stricter international passive house criteria for heating energy use is not met [8].

The air leakage rate of the house was measured to $0.25 \mathrm{l} /\left(\mathrm{s} . \mathrm{m}^{2}\right)$, which is higher than the targeted value which was used also for the design-stage simulation (Table 1). Still, the measured air leakage rate complies with both Swedish and the international passive house criteria. 


\section{Discussion and conclusion}

The simulated (design-stage) and measured (operational-stage) amount of energy used for heating the studied passive house "Sjunde huset" in Kiruna during one year of operation were found to be in the same range. Yet, the simulated heating energy use was somewhat higher than the actual, measured one. This result is likely linked to the fact that the house remained essentially unoccupied throughout the measured year, which meant that no domestic hot water was used and a low indoor temperature remained unnoticed. Consequently, the heating system was not properly adjusted. The simulated and measured heating energy use showed similar variations over the year, with considerably higher values during the winter than during the summer months. Still, the house needed active supply of heating even at times during the summer months due to the subarctic climate; for example, the outdoor temperature in July was ranging between $9-20^{\circ} \mathrm{C}$. The simulations showed that the heating energy use can be expected to decrease as residents eventually move into the apartment and contribute with body heat as well as heat gains from their use of electric equipment and hot water. However, in case the heating system yet again would be malfunctioning and the indoor temperatures drop to uncomfortably low levels occupants could be expected to start using extra heating devices, which would lead to increase the heating energy use. Measurements are still on-going, not just regarding the heating energy use but also regarding other factors affecting the total building energy use, and future work are targeting more detailed evaluations as the house becomes permanently and fully occupied.

The evaluation of the measured indoor temperature turned out to be difficult since the heating system was not working properly throughout the measured period. This problem was not detected until November as the building was unoccupied. However, the system was then adjusted, and, after that, the indoor temperatures remained stable even when outdoor temperatures reached down to $-20^{\circ} \mathrm{C}$. This shows the importance of a properly functioning and well-maintained heating system, especially in cold climates where indoor temperatures otherwise can turn uncomfortably low. Furthermore, overheating, with indoor temperatures of up to $33{ }^{\circ} \mathrm{C}$, was noticed in nearly all evaluated rooms during the studied summer month (July), while the outdoor temperature remained moderate (around $20^{\circ} \mathrm{C}$ ). This showed clearly that the solar radiation had a big impact on the indoor temperature in "Sjunde huset". Consequently, the effect of solar radiation on indoor temperature levels needs to be further evaluated.

Both the simulated and the measured heating energy use of "Sjunde huset" fulfils the Swedish passive house criteria, which was the target for the demonstration. However, the simulated values are about two times higher than the international passive house criteria for heating energy use. Hence, even though this house has a very well- insulated thermal envelope that fulfils the criteria regarding maximum air leakages, the international passive house criteria seem hard to reach in the sub-arctic climate of Kiruna. 


\section{Acknowledgment}

We greatly acknowledge the financial support of Vinnova (Sweden's Innovation Agency), HLRC (Hjalmar Lundbohm Research Center) and the partner companies through the project Attract (Attractive and Sustainable Cities in Cold Climates) and of the European Union Interreg North program through the project EEBAK (Energi Effektiva Byggnader i Arktiska Kommuner).

\section{References}

1. Risberg, D., Vesterlund, M., Westerlund, L., \& Dahl, J.: CFD simulation and evaluation of different heating systems installed in low energy building located in sub-arctic climate. 2015, vol 89, pp.160-169, Building \& Environment, 2015.

2. Mukhopadhyaya, P., MacLean, D., Korn, J., Van Reenen, D., \& Molleti, S.: Building application and thermal performance of vacuum insulation panels (VIPs) in Canadian subarctic climate (2014), vol 85, pp. 672-680. Energy and buildings, 2014.

3. Vladyková, P., Rode, C., Nielsen, T. R., \& Pedersen, S.: Passive Houses for Arctic: Measures and Alternatives. In 13th International Passive House Conference, Germany 2009.

4. NCC Report. Sjunde huset -ett lågenergiparhus i Kiruna, Slutrapport 38548-1,Energymyndigheten, May 2017.

5. SVEBY: Branschstandard för energi i byggnader. Brukarindata för energiberäkningar i bostäder. Projektrapport, April, 2009.

6. Swedish Meteorological and Hydrological Institute (SMHI) Homepage, https://opendatadownload-metobs.smhi.se/explore/?parameter=0, last accessed 2017/09/14.

7. FEBY (Forum for energy-efficient buildings) Homepage, http://www.nollhus.se/, last accessed 2017/09/14

8. Passive House Institute Homepage (Passivhaus Institute), www.passiv.de, http://www.passiv.de/downloads/03_building_criteria_en.pdf. Last accessed 2017/10/15 